\title{
English Language Materials Development: Text-Driven Framework as an Approach
}

\author{
Sayed Ahmad Al-Mousawi ${ }^{1}$ \\ ${ }^{1}$ Kuwait University \\ Correspondence: Sayed Ahmad Al-Mousawi, Kuwait University.
}

Received: September 28, 2020

Accepted: October 19, 2020

Online Published: October 22, 2020

doi: 10.5539/elt.v13n11p40

URL: https://doi.org/10.5539/elt.v13n11p40

\begin{abstract}
This paper sets out to explore English language materials development since the emergence of communicative language learning (CLT). Many pedagogical approaches have been innovated to reach the goal of CLT. It will discuss the most common approach of English language materials development used nowadays. This paper specifically introduces a new approach of English language materials development that aims to match second language acquisition principles which will optimize the language learning process. This new approach is called the Text-driven approach which aims to develop activities around an engaging text, in appose to many approaches that aims to find a text meeting their activities purpose. A full 60 minutes lesson based on this framework is presented and discussed in depth to clarify how it can facilitate language acquisition. Further research ideas are then proposed to enrich this field of study.
\end{abstract}

Keywords: CLT, materials development, text-driven framework, task-based learning, PPP

\section{Introduction}

In the field of teaching English as second language, English language materials plays an essential role in delivering the language knowledge to the learners. Since most institutions use English language coursebooks because bit helps teachers to save time and also help the institutions to increase the face validity of their syllabus (Tomlinson and Masuhara 2018). Thus, there is the need for ongoing research on the best way possible to design these materials to optimize the learning experience.

\section{Literature Review}

\subsection{Pedagogical Approaches in Materials Development}

With the development of communicative language learning (CLT) in the 1970s which stress that the knowledge of linguistic forms is not enough, and that a need to put knowledge into use in communication is necessary (Hedge, 2000). Specifically, communicative competence is the ability to use linguistic knowledge effectively in the real world. Learners need to be encouraged to communicate their ideas and opinions. Richard (2006) argues that to achieve communicative language learning, learners need to be provided with opportunities to interact in meaningful conversations that are as close to real-life communication as possible, and in which real information is exchanged between pairs. In addition, Hedge (2000) points out that if the goal of teaching communicative competence is to equip learners with the knowledge necessary to deal with real-life language. It is important to note that within CLT there are two main versions; strong version and a weak version of CLT. A strong version of CLT promotes avoiding the use of focus on form approach in class, rather the form will be implicitly acquired by using language and focusing only on meaning and nothing else. A weak version of CLT is defined by Cook (2003: 36): CLT has the purpose of shifting "from emphasis on form to emphasis on communication", in other words, communication is more important than form, however, form should not be neglected.

CLT generated two main language learning pedagogy for English language materials development to fulfil CLT principles which are Presentation, practice, production (PPP) and Task-based Learning (TBL), which have a great impact on coursebooks we have in hand nowadays. The PPP has three stages, the first stage delivers for examples a grammar rule or some pre-vocabulary that learners will need in order to help them in the next stage. The practice stage allows learners to practice what they have been presented previously. The final stage will act as a guide rather than as an informant or conductor, this will help learners to "use the language for themselves" (Anderson, 2016: 219). Learners will feel freer in using language without an unwanted intervention from the 
teacher. While PPP started to be popular among SLA scholar, many researchers started to criticize this model of teaching. For instance, Scrivener (1996, as cited by Anderson, 2016: 222) called it a 'teacher-centred' driving the learners away from personal challenging. Willis \& Willis (1996) argues that the production stage of PPP has no real communicative language use because learners are producing language according to the teacher's terms instead of producing language for a communicative purpose. They also address that learners in the third stage might take it as a chance to display their understanding of the newly acquired form rather than a chance to communicate fluently in an authentic context. The TBL model, which is underpinned by the interaction approach, came as a result of the limitations found in the PPP model (Mackey, Ziegler and Bryfonski, 2016). TBL allows learners to use their own linguistics recourses to develop a meaningful exchange for a real purpose; this will also develop real use of language (Willis \& Willis, 1996). Tasks in TBL does not only focus on meaning-based learning, tasks must contain certain components to engage learners cognitively (Mackey, Ziegler and Bryfonski, 2016). TBL can be seen a flipped version of PPP, where the first stage is the production stage and the final stage presents activities based on language focus. That is to say that TBL approach is also concerned with accuracy along with fluency (McDonough et al. 2013).

Recently Tomlinson (2013a) assessed six global course books on whether they match the main second language acquisition (SLA) principles agreed on in the field of applied linguistics and found a weak match between them. Tomlinson (2013a: 12-15) stress that second Language acquisition researchers generally agree that the following principles can maximize the acquisition of language:

1. A rich and meaningful exposure to language in use

2. Affective and cognitive engagement

3. Utilisation of mental resources typically associated with first language (L1) communication

4. Noticing how L2 is used

5. Opportunities for purposeful communication in L2

6. Encouragement to interact

7. Being allowed to focus on meaning

In Tomlinson (2013a) evaluation of six global coursebooks he found that two of the SLA principles above scored zero out of five in all six global course books: a) Utilization of the resources of the brain b) Making use of non-linguistics communication (Tomlinson, 2013a). This lead Tomlinson (2013b) to the development of the text-driven framework, which is an approach to materials development centred around the selection of an engaging text (McDonough et al. 2013). The text chosen should stimulate activities and tasks that satisfy the SLA principles above. In addition, Tomlinson (2013b) argues that the text must be authentic and push learners' brains to achieve multidimensional representation of the text.

In summary, from the above, we now know that the development of CLT lead to major innovation in English language materials development from PPP to TBL to Task-based Framework. It is also clear to say that both TBL and Task-based Framework are designed to meet CLT and SLA principles. However, TBL seems to reflect and weak version of CLT (language focus is required) and Tomlinson's framework seems to represent the strong version of CLT (language focus is not required).

\subsection{Authenticity of Texts and Tasks}

The use of authentic text has been endorsed by several scholars for teaching the use of language in real-life situations and for exposing learners to meaningful language in use (Tomlinson \& Masuhara 2018). Guariento and Morley (2001: 347) argue that authentic texts are motivating because students feel that they are learning 'real language' which they would encounter when communicating in the target language.

On the other hand, tasks can also be authentic in the sense that learners use meaningful real-life language which is typical outside the classroom. Tomlinson \& Masuhara (2018) advocate that most tasks should be authentic to prepare learners for language in day-to-day communication. For example, of an authentic task can be used to asks learners to write a YouTube comment in response to a song that they have experienced and engaged with. The comment should be written in one or two sentences which is how YouTube comments are commonly written. People do not generally write a complete paragraph for a YouTube comment. This exercise helps learners practise the use of real-life language. 


\subsection{Creating Your Own Materials}

Ottley (2016) criticized the English language coursebooks being "One Size Fit All”. In his focus group study on Kurdish learners, he found that the learners would very much appreciate if they could have materials topics that they can relate to and engage with. Noting that the problem with coursebook materials that they are aiming to create materials that will fit all students in the world. Similar, Tomlinson and Masuhara (2018) state that global English language learning materials should be designed and used as a resource. That is to say, teachers have the option to choose from the texts and activities available to them and not to be imposed. Tomlinson's text-driven framework can solve such problem if every school or institute creates their own English language teaching materials which bares in mind learners' needs and wants to engage them as much as possible. Al-Busaidi and Tindle (2010) tested the text-driven framework in their study which sets out to measure the impact of in-house materials development for language learners. They created their own English language materials to which was tailored according to their students' needs and wants. In their study, to test the effectiveness of the materials, they used a pre-use evaluation method and conducted a survey on both the students that experienced the materials and on the teachers. Both students and teachers had mostly positive attitudes towards the materials. However, the writing sample analysis they did on students' writing, before they experienced the materials and afterwards, found that there was an improvement in the students' writing skills. It would be more valid for the study if they had taken another writing sample from the students several weeks later to see whether they still maintained their improvements, had improved further, or had gone back to their previous writing style.

\subsection{Materials Adaptation}

Materials adaptation is another way to avoid the problem of the coursebooks being on size fit all. Tomlinson and Masuhara (2018: 82) define materials adaptation as "the process that involves making changes to existing materials to better suit specific learners, teachers and contexts". That is to say teachers take the materials they are given by their institution and make more relevant for their agenda. For example, if they feel that the coursebooks lacks focus on communicative competence they could change some activities around to make it as communicative as possible. In fact, Masuhara (2006) argues that adapting materials has great benefits in developing teachers' skills by having teachers think critically and evaluate the materials they have in hand. Foster and Hunter (2016) argue that it is reasonable that institution is not buying a new set of coursebooks each year to follow the new trends in SLA. Thus, they believe that adapting the materials for whatever reason, whether it is not engaging for the learners or it follows an old-fashion pedagogical approach is much more practical to do.

However, this paper sets to demonstrate how each school or institution can easily create their own English language learning Materials which can be more engaging to their learners and follow the recent SLA approaches in their material to maximise language acquisition by following the text-driven approach which will be demonstrated in details in the next sections.

\section{Method}

\subsection{Developing the Lesson}

The unit is designed to teach a mixed culture/ethnicity/nationality class in the UK. All students are adults; however, their gender and age are varied. The materials in the lesson focus on differences between people and how all people should accept the differences between them. We believe this topic will highly engage the students considering they are all foreigners in the UK which means they have probably experienced how people are different in the way they think, live, and even eat. The materials in this unit aim to incorporate all seven second language acquisition (SLA) principles.

\subsection{Text Selection}

We believe cultural issues will be more engaging in visual text because videos illustrate not only how language is used but also provide context, showing relevant body language and how culture plays a role in using language (Sherman, 2003 as cited in McCullagh, 2017; McGrath, 2016). We believe that the text is highly relevant to the lesson's objective of raising cultural awareness.

\subsection{Text-Driven Materials}

This unit is based on Tomlinson's (2013b) text-driven framework (see Figure 1), which is designed to follow the SLA principles. One goal of the text-driven framework is to provide learners with a relaxed and enjoyable experience rather than a controlled practice which, according to Tomlinson (2011), has little research demonstrating its importance in SLA. 


\subsection{Text-Driven Stages}

Referring to Figure 1, there are five stages of the text-driven framework. This section will provide an example of each stage in sequence, referring to materials in the unit for examples. Please refer to the full lesson in appendix 1 .

\begin{tabular}{|c|c|c|}
\hline Stages & Learner activities & Principles \\
\hline 1 Readiness activities & $\begin{array}{l}\text { Thinking about something } \\
\text { personal which will help the } \\
\text { learners to connect with the } \\
\text { content of the core text. }\end{array}$ & $\begin{array}{l}1 \text { Personal connection. } \\
2 \text { Visual imaging. } \\
3 \text { Use of inner speech. }\end{array}$ \\
\hline 2 Experiential activities & $\begin{array}{l}\text { Linking the images and } \\
\text { thoughts from the readiness } \\
\text { activities to the text when } \\
\text { first experiencing it. }\end{array}$ & $\begin{array}{l}1 \text { Personal connection. } \\
2 \text { Visual imaging. } \\
3 \text { Use of inner speech. } \\
4 \text { Affective and cognitive } \\
\text { engagement. } \\
5 \text { Use of high-level skills. } \\
6 \text { Focus on meaning. }\end{array}$ \\
\hline $\begin{array}{l}3 \text { Intake response } \\
\text { activities }\end{array}$ & $\begin{array}{l}\text { Developing and then } \\
\text { articulating personal } \\
\text { responses to the text. }\end{array}$ & $\begin{array}{l}1 \text { Personal connection. } \\
2 \text { Visual imaging. } \\
3 \text { Affective and cognitive } \\
\text { engagement. } \\
4 \text { Use of inner speech. } \\
5 \text { Interaction. }\end{array}$ \\
\hline 4 Development activity 1 & $\begin{array}{l}\text { Developing the text by } \\
\text { continuing it, relocating it, } \\
\text { changing the writer's views, } \\
\text { personalizing it, responding } \\
\text { to it etc. }\end{array}$ & $\begin{array}{l}1 \text { Personal connection. } \\
2 \text { Visual imaging. } \\
3 \text { Use of inner speech. } \\
4 \text { Affective and cognitive } \\
\text { engagement. } \\
5 \text { Use of high-level skills. } \\
6 \text { Focus on meaning. } \\
7 \text { Interaction. } \\
8 \text { Purposeful } \\
\text { communication. }\end{array}$ \\
\hline 5 Input response activity & $\begin{array}{l}\text { Focusing on a specific } \\
\text { linguistic, pragmatic, } \\
\text { discourse, genre or cultural } \\
\text { feature of the text in order } \\
\text { to make discoveries about } \\
\text { its use. }\end{array}$ & $\begin{array}{l}1 \text { Personal connection. } \\
2 \text { Visual imaging. } \\
3 \text { Use of inner speech. } \\
4 \text { Affective and cognitive } \\
\text { engagement. } \\
5 \text { Use of high-level skills. } \\
6 \text { Interaction. } \\
7 \text { Noticing. }\end{array}$ \\
\hline 6 Development activity 2 & $\begin{array}{l}\text { Revising the first draft from } 4 \\
\text { above making use of their } \\
\text { discoveries in } 5 \text { above. }\end{array}$ & As for 4 . \\
\hline
\end{tabular}

Figure 1. Task-driven Framework

\section{First Stage: Readiness Activity}

In this stage, students should establish a connection between the text's subject and their own lives using their inner speech before experiencing the text directly. The first activity involves talking to a partner in response to a question. Activity 1 gives the following instructions: 'In pairs, discuss whether you think any of the nationalities/people pictured above might have prejudice against each other.' This will require learners to share their previous knowledge, allowing them to make strong connections when they experience the text (Tomlinson, $2013 \mathrm{~b}$ ) which is similar to the question that they discussed. Activity 1 also personalizes the conversation as seen in Question B: 'describe to the person sitting next to you how you identify a typical person from your country' which will lead to an authentic and meaningful communication (Bao, 2013).

\section{Second Stage: Experiential Activity}

The main goal of the experiential stage is to allow learners to use their multi-dimension skills which is what people normally do in their native language (Tomlinson, 2013a; Tomlinson, 2013b). This activity is done individually while listening to the text to prevent any distraction from the process of forming a mental representation of the text. During the entire experience of watching the video, including the two pauses, the students will think for themselves without using any production skills such as writing or speaking (Tomlinson, 2013b). The video will pause at two key points, and students will be given a question to maximise the likelihood of mental processing of the text. The first pause question asks learners to think about what will happen in the 
next part of the video. The second question asks, 'What would the DNA journey of the following two participants would be like?' This will encourage learners to think deeply about the content of the text and to make predictions based on the questions. The text will also evoke learners' feelings which will engage them affectively and cognitively (Tomlinson, 2013a).

\section{Third Stage: Intake Response Activity}

Tomlinson (2013b) states that in the third stage, the learners should reflect on their opinions and feelings towards their mental representation of the text rather than on comprehension questions. For example, in Activity 3 learners are asked to reflect on their opinion of the main theme of the text, which is that "people have more in common with the world than you think'. Students discuss in pairs whether they disagree or agree, and this can establish a debate in the class reflecting opinions and feelings rather than a discussion of linguistic elements.

\section{Fourth Stage: Development Activity}

At this point, learners are required to produce language related to the text and their own lives (Tomlinson, 2013b). Activity 4 asks students to write what their own DNA journey would be like if they had the test. This should engage learners cognitively by asking them to predict their journey and should also engage them affectively by referring to their own lives. The activity also instructs students to consider, if they had written their DNA journey before watching the video, would it match what they wrote after watching the video? This question reconnects the students with the experience of the people in the video.

\section{Fifth Stage: Input Response Activity}

The final stage aims to allow learners to think about the text critically and in depth (Tomlinson, 2013b). Activity 5 asks students to discuss in their groups whether DNA test should be compulsory and whether this would help end extremism. The intent is to push students to think deeply about the statement and then start a debate, as suggested by Tomlinson (2013b). By debating the statement, learners will be exposed to several perspectives in their groups. Then the debate will take place between all groups which will help students to understand the text and its objectives more deeply.

\section{Discussion: Matching the Unit with SLA Principles}

\section{Principles One and Seven}

According to Tomlinson (2010), in order to ensure that learners are exposed to a rich and comprehensible input of language, the materials should allow learners to experience language in use which is meaningful to the targeted learners. Tomlinson also argues that the texts should be authentic and show how language is used in context. The materials incorporate this principle because the texts are authentic and address cultural awareness, which is one of the unit objectives and is meaningful to the learners because they live in foreign country. For example, the materials enables learners to discusses how people from different cultures and backgrounds are related to each other, encouraging learners to connect the text with their own lives (Tomlinson, 2016).

\section{Principle Two}

It is argued in SLA research that when students feel an emotional connection and think about the text they are experiencing, they are more likely to acquire the language that they have been exposed to (Tomlinson, 2013a; Tomlinson, 2010; Tomlinson 2016). This engages the learner cognitively through the achievable challenge of predicting (Tomlinson, 2016).

\section{Principle Three}

Tomlinson (2010) argues that mental resources typically used in L1 are rarely used in L2. He states that learners should use their inner speech to connect the text they have experienced to their own lives. This means follow-up activities after experiencing the text should encourage students to visualize and use their inner speech in order to complete the activity (Tomlinson, 2010; Tomlinson, 2013a). This is exemplified in Activity 4, which asks learners to imagine what their results would show if they had the DNA test.

\section{Principle Four}

Ellis (2016) stress that implicit knowledge is essential for learners' communicative skills, without it learners will feel challenged to communicate effectively. According to Tomlinson (2013a; Tomlinson, 2010) the more learners invest to pay attention to how language is used, the more likely they are to acquire the language. Thus, for example, we have decided to avoid pre-vocabulary teaching as it minimizes implicit knowledge that learners will acquire. Another reason is that communicative competence is one of the unit's objective and perhaps the main reason for learners to learn in this course. Drawing back to Ellis (2016) argument on the relation between 
implicit knowledge and communicative skills, it appeared reasonable to relay on learners' ability to notice language in use and acquire it as implicit knowledge.

Principles Five and Six

SLA scholars argue that learner output, especially when asking them to talk about something which is not easily expressed, is as important as comprehension input (Tomlinson, 2013a). Tomlinson adds that learners should be encouraged to speak by designing the activity in a way which appears purposeful and meaningful to the learner. In Activity 1, learners are required to describe a typical person from his or her country to a partner and then ask the partner if the description matches what he or she predicted a typical person from that country would be like.

Conclusion \& further research

This paper has discussed the main approach in English language materials development since the emergence of CLT and has discussed how SLA and English language materials development can come into harmony. It has also demonstrated what a strong version of CLT materials would look like with justification on each task from a SLA perspective.

It seems to me that the next move would be taking Tomlinson (2013b) idea of Task-driven materials development can be also employed in the context of Mobile-assisted language learning. The idea is that an educator takes a generic app which are that are not designed for language learning app. Say we take Twitter for example, and develop activities around the app which can be either done at home by the learners or as part of in-class activities. This should also follow Tomlinson's stages for materials development which matches the main SLA principles. Also, it will probably prompt learners to have access to learn independently. Dudeney, et. al (2013) have many ideas that are based around generic apps. However, I would think it would be interesting if these activities were following the Task-driven Framework. This usage of apps for language learning is what Achilleos \& Jarvis (2013) calls Mobile-assisted language use (MALU), where learners are using apps that are not been specifically designed for language learning but use it for non-linguistic outcomes. Jarvis argues that this approach will expose learners to authentic texts and language used in real life which allows them to unconsciously pick up language, also known as implicit language learning.

\section{Acknowledgments}

I would like to extend my gratitude to Elettra Boniolo, Kerry Brighton, Gerard Walmsley, and Tian Ye for their contribution in developing the lesson plan which was part of our MA TESOL coursework at the University of Liverpool.

\section{References}

Achilleos, M., \& Jarvis, H. (2013). From Computer Assisted Language Learning (CALL) to Mobile Assisted Language Use (MALU). In TESLEJ, 16, 4.

Al-Busaidi, S., \& Tindle, K. (2010). Evaluating the effect of in-house materials on language learning. In B. Tomlinson \& H. Masuhara (Eds.), Research for materials development in language learning: Evidence for best practice (pp. 137-149). London: Continuum.

Anderson, J. (2016). A potted history of PPP with the help of ELT Journal. ELT Journal, 71(2), 218-227. https://doi.org/10.1093/elt/ccw055

Bao, D. (2013). Developing materials for speaking skills. In B. Tomlinson (Ed.), Developing materials for language teaching (2nd ed., pp. 407-428). London: Bloomsbury.

Dudeney, G., Hockly, N., \& Pegrum, M. (2013). Digital literacies. Milton Park: Taylor \& Francis. https://doi.org/10.4324/9781315832913

Ellis, R. (2016). Language teaching materials as work plans: An SLA perspective. In B. Tomlinson (Ed.), SLA research and materials development for language learning (pp. 203-218). New York: Routledge.

Foster, P., \& Hunter, A. (2016). When it's not what you do, but the way that you do it: How research into second language acquisition can help teachers to make the most of their classroom materials. In B. Tomlinson (Ed.), SLA research and materials development for language learning (pp. 280-292). New York: Routledge.

Guariento, W., \& Morley, J. (2001). Text and task authenticity in the EFL classroom. ELT Journal, 55(4), 347-353. https://doi.org/10.1093/elt/55.4.347

Hedge, T. (2000). Teaching and learning in the language classroom. Oxford: Oxford University Press. 
Mackey, A., Ziegler, N., \& Bryfonski, L. (2016). From SLA research on interaction to TBLT materials. In B. Tomlinson (Ed.), SLA research and materials development for language learning (pp. 103-118). New York: Routledge.

Masuhara, H. (2006). Materials as a teacher development tool. In J. Mukundan (Ed.), Readings on ELT materials II (pp. 34-46). Petaling Jaya: Pearson Malaysia.

McCullagh, M. (2017). Authentic Video: Using a Text-driven Approach In Maley, A. \& Tomlinson, B. (Eds) Authenticity in Materials Development for Language Learning (pp. 247-259). Newcastle-upon-Tyne: Cambridge Scholars Publishing.

McDonough, J., Shaw, C., \& Masuhara, H. (2013). Methods in ELT: A Teacher's Guide, 3rd ed. Retrieved from https://www-dawsonera-com.liverpool.idm.oclc.org/abstract/9781118357484

McGrath, I. (2016). Materials evaluation and design for language teaching (2nd ed.). Edinburgh: Edinburgh University Press.

Ottley, K. (2016). Why One Size-Fits-All is Not Fit for Purpose. In B. Tomlinson (Ed.), SLA research and materials development for language learning (pp. 268-279). New York: Routledge.

Richards, J. C. (2006). Communicative Language Teaching Today. Language Teaching (Vol. 25). NY: Cambridge University Press. https://doi.org/10.2307/3587463

Tomlinson, B. (2010). Principles of effective materials development. In N. Harwood (Ed.), English language teaching materials -theory and practice (pp. 81-108). New York: Cambridge University Press.

Tomlinson, B. (2011). Principles and procedures of material development. In B. Tomlinson (Ed.), Materials development in language teaching. Cambridge: Cambridge University Press.

Tomlinson, B. (2013a). Second language acquisition and materials development. In B. Tomlinson (Ed.), Applied linguistics and materials development (pp. 11-29). London: Bloomsbury.

Tomlinson, B. (2013b). Developing principled frameworks for materials development. In B. Tomlinson (Ed.), Developing materials for language teaching (2nd ed., pp. 95-118). London: Bloomsbury.

Tomlinson, B. (2016). SLA research and materials development for language learning Ch 1 (p. 3-23). New York: Routeldge. https://doi.org/10.4324/9781315749082

Tomlinson, B., \& Masuhara, H. (2018). The complete guide to the theory and practice of materials development for language learning. Hoboken, NJ: WILEY Blackwell.

Willis, J., \& Willis, D. (1996). Challenge and Change in Language Teaching. Oxford: Heinemann. 


\section{Appendix 1}

DNA Journey Lesson

\section{Activity 1}

A) In pairs, discuss whether you think any of the nationalities/people pictured above might have prejudice or admiration for each other?

B) In pairs, describe to the person sitting next to you how you identify a typical person from your country (appearance, interests, food preference etc).

C) Ask your partner if the description matches what they thought a typical person from your country would look and behave like.

\section{Activity 2}

https://www.youtube.com/watch?v=1B7QeJ0dN44

* We are going to watch a video featuring people from different nationalities speaking about their prejudices against other nations.

* While watching the video, consider if you have any similar prejudices to the ones that appear in the video.

\section{$>\quad$ First Pause (1:13)}

Individually, think about what will happen in the next part of the video.

\section{$>\quad$ Second Pause (2:42)}

Individually, try to guess what the DNA journey of the following 2 participants would be like. (For example one participant may be $20 \%$ Turkish $10 \%$ Italian.)
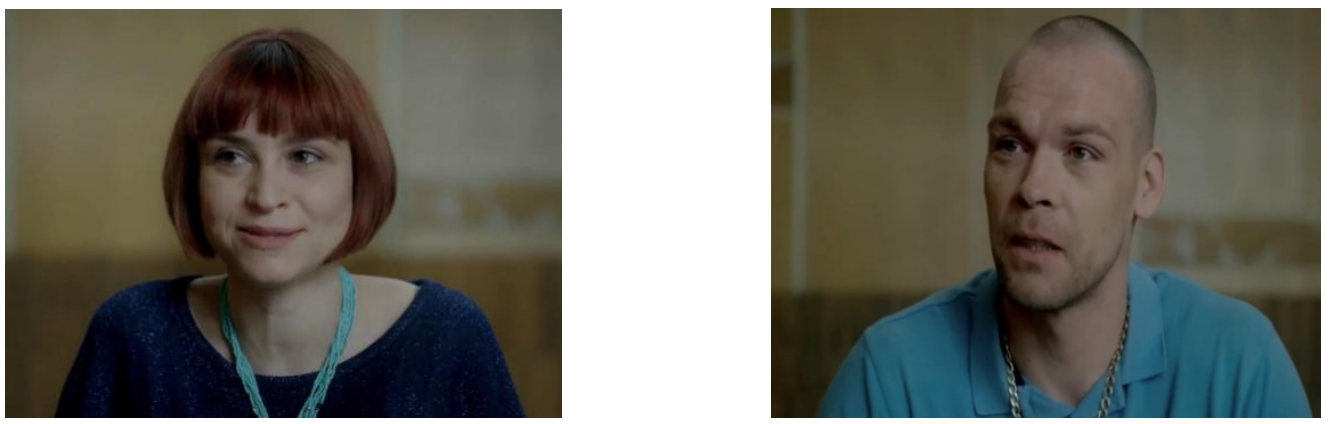

Activity 3

How do you feel about the following comment?

"You have more in common with the world than you think"

Do you agree or disagree with this? Discuss it with your partner.

\section{Activity 4}

Discuss the following questions with a partner:

- If you could have your DNA tested what do you imagine your story would be?

- Does it match what you thought before watching the video? 


\section{Activity 5}

Discuss in your group the following statement and come up with an argument:

Do you agree with the French participant's suggestion that a DNA test should be made compulsory, and that it could help end extremism?

\section{Reference}

YouTube Website: The DNA Journey accessed 20/3/19

https://www.youtube.com/watch?v=tyaEQEmt5ls

\section{Teaching context:}

This material is designed for non-English mixed international students in a language school in the UK.

\section{Target learners:}

$>$ Proficiency level: intermediate

$>$ Gender: Mixed

$>$ Age: $20-45$

$>$ Occupation: Part-time students

$>$ Needs and wants: General English. Aimed at learners willing to relocate to the UK for work and study purposes, looking to improve their general English, in particular their communication skills.

> Class size: 16 students

$>$ Class time: 1 hour / section

\section{Objectives:}

To help the learners:

- To become confident users of spoken English

- To be able to express themselves critically on a variety of topics.

- To develop autonomy in their learning

- To develop Culture awareness, for interaction with people from different countries

- To develop skills to communicate effectively - communicative competence

- To use authentic texts to develop creative ways of learning

- To use speaking activities for negotiation and engagement with peers

- To develop skills to collaborate with others.

\section{Copyrights}

Copyright for this article is retained by the author(s), with first publication rights granted to the journal.

This is an open-access article distributed under the terms and conditions of the Creative Commons Attribution license (http://creativecommons.org/licenses/by/4.0/). 